\section{Effects of polychlorinated dibenzo-p-dioxins and polychlorinated dibenzofurans on phagocytic response of Eisenia andrei cœlomocytes}

\author{
Hayet Belmeskine, ${ }^{1}$ Pauline Brousseau, ${ }^{1}$ \\ Sami Haddad, ${ }^{2}$ Louise Vandelac, ${ }^{3}$ \\ Michel Fournier ${ }^{1}$ \\ 'INRS-Institut Armand Frappier, Laval, \\ Québec; '2Département de santé environ- \\ nementale et santé au travail, Université \\ de Montréal, Quebec; ${ }^{3}$ Département des \\ sciences de l'environnement de l'univer- \\ sité du Québec à Montréal, Montréal, \\ Québec, Canada
}

\section{Abstract}

The immunotoxicological effects of polychlorinated dibenzo- $p$-dioxins/dibenzofurans (PCDDs/Fs) mixtures on Eisenia andrei earthworms have never been studied. In this work we investigated these effects both for in vitro and in vivo exposure, using the viability and the phagocytic activity of cœlomocytes as immunological biomarkers and the flow cytometry was used for analysis. The in vitro exposure revealed a cytotoxic effect of PCDD/Fs mixture (C2) containing $50 \times 10^{-3} \mathrm{ng} / \mathrm{mL}$ of 2,3 , 7, 8-TCDD and an induction of the phagocytic capacity at the mixture (C1) containing $25 \times 10^{-3}$ $\mathrm{ng} / \mathrm{mL}$ of $2,3,7,8$-TCDD. In the in vivo filter paper exposure, the immunocompetence of earthworms was assessed after 3 h-exposure to mixtures of PCDD/Fs at the levels of $\mathrm{C} 1, \mathrm{C} 2$, $\mathrm{C} 3$ and $\mathrm{C} 4$ containing about; 0.05, 0.3, 0.5 and $0.83 \mathrm{ng}$ of $2,3,7,8-\mathrm{TCDD} / \mathrm{cm}^{2}$, respectively. Morphological observations showed an excessive secretion of mucus and body surface lesions in worms exposed to higher concentrations (C3 and C4), which revealed that these organisms were affected by PCDD/Fs either through skin and/or by feeding. The levels of the extruded cell yield decreased significantly at all the concentrations tested. However, the cell viability was shown to be unaffected by PCDD/Fs concentrations. It was also shown, that exposure to the highest PCDD/Fs concentrations; C2, C3 and C4 inhibited both phagocytic activity and efficiency.

\section{Introduction}

Earthworms have been extensively used as standard test organisms in soil toxicity testing ${ }^{1}$. They have been used to assess environ- mental impact from heavy metals, ${ }^{2-4}$ pesticides $^{5}$ and some persistent organic pollutants (POPs) such as; PCBs, dioxin-like PCBs and PAHs. ${ }^{6-10}$ However, the knowledge on toxic effects of persistent organic pollutants (POPs) upon the worms is still very limited. ${ }^{11,12}$ For example, there is paucity in the literature describing the toxicity of polychlorinated dibenzo-p-dioxins (PCDDs) and polychlorinated dibenzofurans (PCDFs) in earthworms which play an important role in soil formation processes and are considered as interesting bio-indicators for soil contamination. It is well recognized that PCDDs and PCDFs represent the most toxic anthropogenic chemicals in the environment where they enter as by-products of combustion processes. Their toxicity is associated to their stability, lipophilicity, bioaccumulation and high persistence. In addition, previous studies have reported that prolonged exposure to TCDD presents adverse health effects, including immunotoxicity, neurotoxicity, hepatotoxicity and carcinogenesis. ${ }^{13-17}$ Moreover, the international Agency for Research on Cancer (IARC) evaluated TCDD as a Group 1 carcinogen i.e., a human carcinogen. ${ }^{18,19,20}$ Environ mental exposure concentrations of $1 \mathrm{ng} 2378$ TCDD/g soil were considered a level of concern for causing cancer. ${ }^{21}$ Thus, the presence of these toxic contaminants in soils may have direct harmful effects to the terrestrial ecosystem. Previous studies have rewieved a large battery of biomarkers to measure the sublethal effects of chemicals in earthworms, such as the immunological responses. Since the immune responses are important host defense mechanisms, their modulation may result in increased incidence of infections that could influence the survival of individuals and their populations. $^{22}$ It has been demonstrated that many chemicals, including organic and inorganic trace elements, may adversely affect the immune system of earthworms. ${ }^{23}$ In fact, it has been shown that the exposure to mercury, cadmium or zinc was toxic and affected cell viability and phagocytosis. ${ }^{23-26}$ In addition, Goven $e t$ $a l$. and Ville et al. showed that the phagocytic competence was also inhibited by polychlorinated biphenyls (PCBs). ${ }^{6,7}$ Thus, the suppression of the phagocytic activity or reduction of cœlomocytes viability decreases animal resistance to infection. ${ }^{23}$ This deficiency in immune functions is considered as a sign of toxic effects of environmental pollutants. ${ }^{23}$

To date, the immunotoxicological effects of PCDD/Fs on earthworms have not been studied. Thus, the objective of the present study was to investigate, in vitro and in vivo, the effects of PCDD/Fs mixtures on the immunocompetence of oligochaete Eisenia andrei using the pagocytosis assay as immunological biomarker.
Correspondence: Hayet Belmeskine, INRSInstitut Armand Frappier, 531 boulevard des prairies, Laval, Québec, Canada H7V1B7.

Fax: +1.450.686.5801.

E-mail: hayet.belmeskine@iaf.inrs.ca/ hbelmeskine@hotmail.com

Key words: PCDDs/Fs, earthworms, Eisenia andrei, immunosuppression, phagocytosis, cœlomocytes.

Acknowledgments: this work was conducted in the environmental immunotoxicology laboratory at Institut Armand Frappier (IAF-INRS). The financial support has been provided by the Canada Research Chair in Environmental Immunotoxicology (Dr. Michel Fournier). The authors are thankful to Marlene Fortier and also appreciate her excellent technical assistance. We wish to thank Dr Pierre Yves Robidoux (CNRCIRB), Louis Martel and Elloise Veilleux (CEAEQuebec) for earthworms donations.

Received for publication: 8 June 2011.

Accepted for publication: 6 October 2011.

This work is licensed under a Creative Commons Attribution NonCommercial 3.0 License (CC BYNC 3.0).

(C) Copyright H. Belmeskine et al., 2011

Licensee PAGEPress, Italy

Journal of Xenobiotics 2011; 1:e6

doi:10.4081/xeno.2011.e6

\section{Materials and Methods}

\section{Chemicals}

The mixture of PCDDs/Fs in nonane solution was obtained from Wellington laboratories (Ontario, Canada) and stored at $1^{\circ} \mathrm{C}$. Dimethyl sulfoxide 99.5\% (DMSO), Formaldehyde 37\% and phosphate buffer solution (PBS) were obtained from Sigma-Aldrich (St. Louis, MO, USA). Bovine serum albumin (BSA) was purchased from MP Biomedicals, LLc (Cliveland, Ohio, USA) and sodium azide $\left(\mathrm{NaN}_{3}\right)$ from FicherChemical (Pittsburgh, PA, USA). Purified water was obtained from a Milli- $Q$ water purification system.

\section{Earthworms}

The earthworms, Eisenia andrei were purchased from the Carolina Biological Supply (Burlington, NC, USA). Prior to the experiment, the animals were maintained in earthworm bedding (Magic Products, Amherst, Jct, WI) at $20 \pm 1^{\circ} \mathrm{C}, 70-80 \%(\mathrm{w} / \mathrm{w})$ moisture and 12:12 h light/dark cycle, and fed once a week with cereals (Magic Worm Food, Magic Products Inc., Amherst Junction, WI, USA).

\section{Cell extrusion}

Cœlomocytes were extracted by inserting a 
single worm into a 15-mL tube containing $3 \mathrm{~mL}$ of Lumbricus balanced salt solution (LBSS) composed of $1.5 \mathrm{mM} \mathrm{NaCl}, 4.8 \mathrm{mM}$ KCL, 1.1 $\mathrm{mM} \mathrm{MgSO}_{4} .7 \mathrm{H}_{2} \mathrm{O}, 0.4 \mathrm{mM} \mathrm{KH_{2 }} \mathrm{PO}_{4}, 0.3 \mathrm{mM}$ $\mathrm{Na}_{2} \mathrm{PO}_{4} \cdot 7 \mathrm{H}_{2} \mathrm{O}, 3.8 \mathrm{mM} \mathrm{CaCl}$, and $4.3 \mathrm{mM}$ $\mathrm{NaHCO}_{3}{ }^{27,28,24}$ The liquid medium in the tube was submitted to a $6 \mathrm{~V}$ current for $20-30 \mathrm{~s}$ using aluminium wires. ${ }^{25}$ Following the electric shock, a higher turbidity was observed in the solution. Then, the worm was removed from the tube and the solution was gently shaken. Total number of cells and initial cell viability were determined by diluting $20 \mu \mathrm{L}$ of cell suspension with $20 \mu \mathrm{L}$ of $0.4 \%$ trypan blue (Sigma-Aldrich) and this cell suspension was placed into an improved Neubauer haemocytometer which was microscopically observed. ${ }^{24,25}$

\section{The phagocytosis assay}

The phagocytic activity of cœlomocytes was measured in each worm, based on the protocol of Brousseau et al. ${ }^{28}$ For each cell suspension, 1.716- $\mu \mathrm{m}$ fluorescent latex beads (Polysciences Inc., Warrington, PA, USA) were added in a bead: cell ratio of 100:1. The beads were previously sonicated for $5 \mathrm{~min}$ at room temperature to get rid of doublet and triplet beads. The cells (with beads) were then incubated for $18 \mathrm{~h}$ at room temperature. To remove the beads that were not phagocyted, the cell suspension was layered over a $3 \%$ bovine serum albumin (BSA) and centrifuged at 150 $\mathrm{g}, 4^{\circ} \mathrm{C}$ and for $8 \mathrm{~min}$. The cells collected in the pellet were then resuspended in $500 \mu \mathrm{L}$ of hematall (Fisher Scientific, Ottawa, ON, Canada) containing $0.185 \%$ formaldehyde and $0.2 \%$ sodium azide. Then, the phagocytosis was measured by flow cytometry in FL1 (Becton Dickinson, San José, CA, USA) ${ }^{28}$ and for each sample, the fluorescence of 5000 events was recorded. Approximate instrument settings were presented on Table 1. Results were analysed with the Cell Quest Pro software (Becton Dickinson) to determine the percentage of cells that engulfed one bead and more (phagocytic activity) or three beads and more (phagocytic efficiency). The results were expressed as the percentage of phagocytosis.

\section{Exposure protocol}

In our study, we carried out two experiments. The first one consists to study the effects of the PCDDs/Fs dose on viability and phagocytic activity of cœlomocytes, after an in vitro exposure. In the second experiment, we used a filter paper-contact assay to evaluate the in vivo response (viability and phagocytic activity) of the worms.

\section{In vitro exposure to polychlorinated dibenzo-p-dioxins/dibenzofurans}

Before contaminant exposure, the cell solu- tion of each worm was adjusted to $0.5 \times 10^{6}$ cells/mL. To establish the in vitro doseresponse curves, two series of glass tubes containing the cell suspension were exposed to dilutions of a PCDDs/Fs mixture; $\mathrm{C} 1$ and $\mathrm{C} 2$ (Table 2). These dilutions were done in DMSO (final concentration $0.004 \%$ per tube). This DMSO concentration showed no effects on function cell. So, a set of tubes with DMSO (vehicle) was added as negative control and an other set of tubes containing untreated cœlomocytes was added to monitor their viability during the experiments. Cells were exposed for $3 \mathrm{~h}$ to PCDDs/Fs and then the latex beads were added to quantify phagocytosis. The preincubation time of $3 \mathrm{~h}$ was previously optimized (data not shown). PCDD/Fs-incubated cell viability was also monitored in the same time of phagocytosis. It was determined by adding $5 \mu \mathrm{L}$ of PI $(1 \mathrm{mg} / \mathrm{L})$ to the cell suspensions (PI final concentration $10 \mu \mathrm{g} / \mathrm{L}$ ) and measuring fluorescence by flow cytometry in FL3 using a FACSCalibur cytometer (Becton Dickinson, San José, USA). ${ }^{27,28}$ Data are expressed as a percentage of viable cells. Six worms were used and the experiment was repeated two times.

\section{In vivo exposure to polychlorinated dibenzo-p-dioxins/dibenzofurans}

The contact toxicity assay was performed following the method described in the OECD guidelines for the testing of chemicals. ${ }^{1,29}$ Three $h$ prior to the exposure, the worms were removed from the culture, rinsed with water, dampened on filter paper and kept in the dark at $20 \pm 1^{\circ} \mathrm{C}$ in order to allow the removal of the gut content.

Then, volumes of 10, 50, 100 and $150 \mu \mathrm{L}$ of initial mixture solution of PCDD/Fs (diluted in DMSO < 0.01\%) containing; 0.625 ng (2378TCDD)/ $\mu \mathrm{L}, 0.625 \mathrm{ng}(2378-\mathrm{TCDF}) / \mu \mathrm{L}, 1.562 \mathrm{ng}$ (12378-PeCDD)/uL, 1.562 ng (12378PeCDF)/uL, 1.562 ng (123678-HxCDD)/uL, $1.562 \mathrm{ng}$ (123678-HxCDF)/uL, $1.562 \mathrm{ng}$ (1234678-HpCDD)/uL, 1.562 ng (1234678-
HpCDF)/uL, 3.125 ng OCDD/uL and 3.125 ng OCDF/uL, were added to 6-cm diameter plastic Petri dishes containing a No. 3 Whatman filter paper. The resulting exposure concentrations for each volume were illustrated in Table 3 . Negative controls received just deionized water $(200 \mu \mathrm{L})$ were included along the test with controls received DMSO (without PCDD/Fs) to test for any effect due to the solvent (vehicle). Then, the worms were individually rinsed with distilled water, blotted dry on a paper towel, weighed (between 0.3 and 0.6 $\mathrm{g}$ ), and placed in the dish. Four replicates per treatment were used, consisting of one earthworm per Petri dish. All experiments were real-

Table 1. Approximate parameters used for acquisition of phagocytosis Data by flow cytometry.

\begin{tabular}{lc}
\hline Parameters & Value \\
Forward scatter (FSC Lin) & 1.00 \\
FSC threshold & 52 \\
\hline Side scatter (SSC log) & 227 \\
Fluorescence (FL1 log) & 273 \\
\hline Fluorescence (FL3 log) & 650
\end{tabular}

Table 2. Polychlorinated dibenzo-p-dioxins/dibenzofurans concentrations used for dose-response curves: test in vitro.

\begin{tabular}{lcc} 
PCDDs/Fs & $\begin{array}{c}\text { C1 }(\mathrm{ng} / \mathrm{mL}) \\
\mathbf{1} 10^{-3}\end{array}$ & $\begin{array}{c}\mathrm{C} 2(\mathrm{ng} / \mathrm{mL}) \\
\mathbf{1} 10^{-3}\end{array}$ \\
2378-TCDD & 25 & 50 \\
2378-TCDF & 25 & 50 \\
\hline 12378-PeCDD & 62.5 & 125 \\
12378-PeCDF & 62.5 & 125 \\
\hline 123678-HxCDD & 62.5 & 125 \\
123678-HxCDF & 62.5 & 125 \\
\hline 1234678-HpCDD & 62.5 & 125 \\
1234678-HpCDF & 62.5 & 125 \\
\hline OCDD & 125 & 250 \\
OCDF & 125 & 250 \\
\hline
\end{tabular}

$\mathrm{PCDDs} /$ Fs, polychlorinated dibenzo-p-dioxins/dibenzofurans.

Table 3. Initial concentrations of polychlorinated dibenzo-p-dioxin/dibenzofuran in Petri dishes: in vivo exposure.

\begin{tabular}{lcccc} 
PCDD/F & $\mathrm{Cl}\left(\mathrm{ng} / \mathrm{cm}^{2}\right)$ & $\mathrm{C} 2\left(\mathrm{ng} / \mathrm{cm}^{2}\right)$ & $\mathrm{C} 3\left(\mathrm{ng} / \mathrm{cm}^{2}\right)$ & $\mathrm{C4}\left(\mathrm{ng} / \mathrm{cm}^{2}\right)$ \\
2378- TCDD & 0.055 & 0.276 & 0.553 & 0.829 \\
2378-TCDF & 0.055 & 0.276 & 0.553 & 0.829 \\
\hline 12378- PeCDD & 0.138 & 0.691 & 1.382 & 2.073 \\
12378- PeCDF & 0.138 & 0.691 & 1.382 & 2.073 \\
\hline 123678- HxCDD & 0.138 & 0.691 & 1.382 & 2.073 \\
123678- HxCDF & 0.138 & 0.691 & 1.382 & 2.073 \\
\hline 1234678-HpCDD & 0.138 & 0.691 & 1.382 & 2.073 \\
1234678-HpCDF & 0.138 & 0.691 & 1.382 & 2.073 \\
\hline OCDD & 0.276 & 1.382 & 2.765 & 4.147 \\
OCDF & 0.276 & 1.382 & 2.765 & 4.147 \\
\hline PCDDP
\end{tabular}

PCDD/F, polychlorinated dibenzo-p-dioxin/dibenzofuran. 
ized in the dark at $20 \pm 1^{\circ} \mathrm{C}$ for $3 \mathrm{~h}$. The assay was done in duplicate. After $3 \mathrm{~h}$-exposure duration, the worms were again rinsed with distilled water, blotted and individually weighed. Cell extrusion was carried out and the cell yield, viability and phagocytosis were then determined as described above.

\section{Statistical analysis}

The data were expressed as arithmetic means \pm standard deviations. Statistical significances of differences among treatments were determined by ANOVA one-way followed by Tukey HSD post-hoc test for specific comparison of means $(\mathrm{P}<0.05)$, significantly different from the vehicle control: ${ }^{*} \mathrm{P}<0.05$, ${ }^{* *} \mathrm{P}<0.01$, and $* * * \mathrm{P}<0.001$. The software Statistica, Version 6.0 (StatSoft, Tulsa, OK, USA) was used.

\section{Results}

To distinguish cœlomocyte populations by flow cytometry, based on a dot plot of complexity versus the size of the cells, two gates were drawn around cœlomocytes. We observed a population of smaller, complex cells following the SSC axis, corresponding to chloragocytes (G1), and population of larger, simple cells following the FSC axis corresponding to amœbocytes (G2) (Figure 1A). Debris represent the part not gated in Figure 1A. Furthermore, it was also shown that G1 cells do not represent phagocytic activity (Figure 1B) but G2 represents the delimitation of phagocytic cell population (Figure 1C).

\section{In vitro exposure}

In this experiment, cells were exposed to two concentrations of PCDDs/Fs mixture (C1 and $\mathrm{C} 2$ ) during $3 \mathrm{~h}$ before the incubation with beads. The effects of selected concentrations were evaluated by determining cell viability and phagocytic activity. Figures 2 and 3 showed that an increase of PCDDs/Fs concentration can induce changes in viability and phagocytosis profiles, respectively. In fact, a decrease of $10 \%$ in viability of treated cells with $\mathrm{Cl}$, compared to vehicle control, was shown in Figure 2. However, a significant decrease $(\mathrm{P}<0.01)$, greater than $50 \%$ in viability of treated cells with $\mathrm{C} 2$ compared to vehicle control was also observed in Figure 2. A significant induction $(\mathrm{P}<0.05)$ of phagocytic activity was shown, in Figure 3, for cells exposed to C2.

\section{In vivo exposure}

Acute toxicity of $\mathrm{PCDD} / \mathrm{Fs}$ on $E$. andrei earthworms was carried out by paper contact method. In the first minutes of exposure some observations were noticed about worms comportmental as lifting the body and getting longer. After 3 h-exposure duration, no mortality of earthworms was observed in controls and in dishes contaminated with PCDD/Fs. However, mucus secretion was noted in all PCDD/Fs - exposed worms and was excessive for worms exposed to C2, C3 and C4 (Table 3). Also, about $80 \%$ of exposed worms to $\mathrm{C} 3$ and $\mathrm{C} 4$ exhibited surface lesions and other morphological abnormalities like coiling and curling.

The extruded cell yields of worms exposed to the various PCDD/Fs concentrations tested (C1, C2, C3 and C4) were significantly $(\mathrm{P}<0.05)$ lower from the vehicle controls (Figure 4). While, the cell viability (Figure 5) was shown to be unaffected by PCDD/Fs concentrations used in this experiment.

Phagocytic activity (Figure 6) and efficiency (Figure 7) were significantly inhibited, when worms were exposed to C2, C3 and C4 which contained $0.276,0.553$ and 0.829 ng 2378$\mathrm{TCDD} / \mathrm{cm}^{2}$, respectively, compared to vehicle controls.

\section{Discussion}

In Eisenia andrei earthworms, two populations are distinguished; chloragocytes and
A

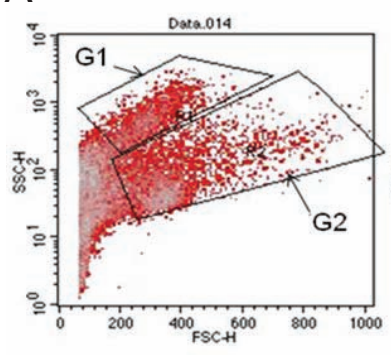

B

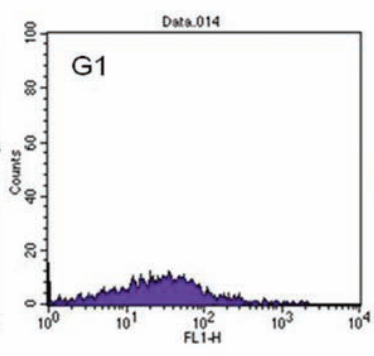

C

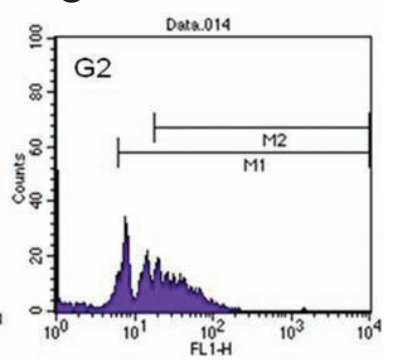

Figure 1. Pattern (A) and fluorescence histograms of Eisenia andrei colomocytes after the phagocytosis assay (B: Chloragocytes, C: amobocytes, M1: cells have engulfed one bead and more, M2: cells have engulfed three beads and more).

amœbocytes (small and large or granular and hyaline).$^{30}$ The gates used to delimitate the phagocytic cell populations showed that only G2 (amœbocytes) which present a phagocytic activity (Figure 1). These results confirms the reported data which showed that in Oligochaeta (Lumbricus terrestris, Eisenia foetida, Eisenia andrei), all cœlomocyte types, with the exception of chloragocytes (chloragogen cells), produce pseudopodia and are capable of phagocytosis. ${ }^{31}$ However, no peaks of fluorescence by cells engulfing beads were obtained for G1 (chloragocytes), the autofluorescence obtained in Figure 1B was due to riboflavin $^{32,33}$ so the chloragocytes had been excluded from analysis in all our experiments.

The results of the in vitro exposure showed that $\mathrm{C} 2$ presents a cytotoxic effect on cœlomocytes (mortality was greater than 50\%) (Figure 2). In addition, the evaluation of phagocytosis in cells exposed to $\mathrm{Cl}$ showed an induction of the phagocytic activity (capacity of cells to engulf one bead and more) compared to vehicle control (Figure 3). The PCDD/Fs-associated immuno-stimulation observed in our study

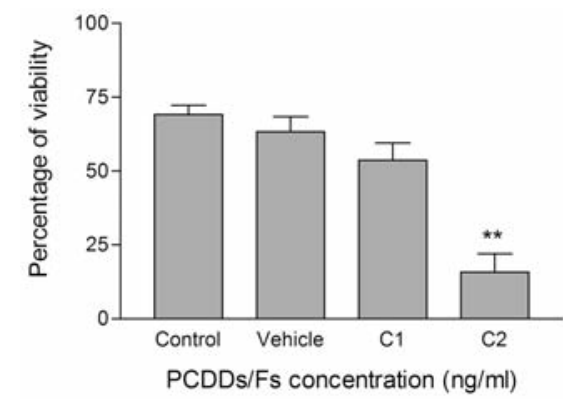

Figure 2. Viability of colomocytes following $3 \mathrm{~h}$ of preincubation with polychlorinated dibenzo- $p$-dioxins/dibenzofurans (PCDDs/Fs) and $18 \mathrm{~h}$ with beads. Data are presented as mean $\pm \mathrm{SD}(\mathrm{n}=6)$, asterisks indicate significant difference $(P<0.01)$ from vehicle.

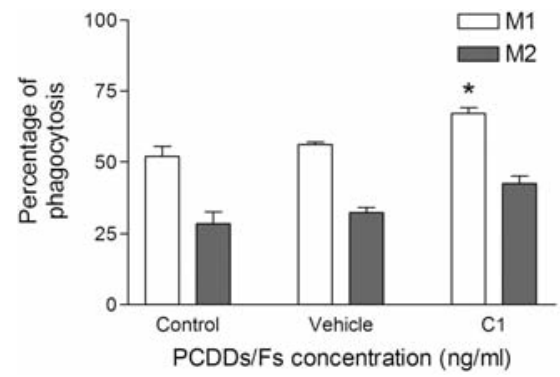

Figure 3. Phagocytic response of cœlomocytes following $3 \mathrm{~h}$ of preincubation with polychlorinated dibenzo-p-dioxins/dibenzofurans (PCDDs/Fs) and $18 \mathrm{~h}$ with beads (M1: cells engulfed one bead and more, M2: cells engulfed three beads and more). Data are presented as mean \pm SD $(n=6)$ and asterisk indicates significant difference $(P<0.05)$ from vehicle. 
was considered as an immunotoxicological effect, since it may result in the loss of regulation within the immune system and can lead to adverse outcomes including autoimmune disease, anergy, and cancer. ${ }^{34,35}$ Also, these stimulatory effects caused by normally inhibitory and toxic substances such as PCDD/Fs may be interpreted as hormesis phenomenon. In fact, hormesis was previously observed in mammalian laboratory models exposed to dioxins. $^{36,37}$ For example; in female SpragueDawley rats exposed to single and multiple doses of 1,2, 3, 4, 6, 7, 8-heptachlorodibenzo- $p$ dioxin (HpCDD) to study its chronic toxicity and carcinogenicity in lifetime experiments, it was noted that the lowest doses prolonged the life of rats, while higher doses resulted in a shortening of their life. ${ }^{36}$

To the best of our knowledge, no other studies examined the effects of PCDD/Fs on phagocytic activity using an invertebrate model, but using just mammalian model. Also, few data of the PCDDs/Fs effects on the phagocytosis are available. Omara et al. have exposed leucocytes from male Fischer rats to PCDDs/Fs mixtures $(1-15 \mathrm{pg} / \mathrm{mL})$ to study the effects on phagocytosis. $^{38}$ Their results indicate that in vitro exposure to this range of concentrations had no suppressive effects on the immune functions assayed, and thus produced no additive immunotoxicity.

The impacts of PCDDs/Fs on vertebrates are known to be mediated through the ligation and activation of the aryl hydrocarbon receptor (AHR). The specific effects of AHR activation by PCDDs/Fs on an immune response are determined by the cell types involved, their activation status, and the type of antigenic stimulus. ${ }^{39}$ However, for the invertebrates, few data are available on the presence of AHR-like and their TCDD dependence. Indeed, AHRhomologs have recently been shown for nematodes (Caenorhabditis elegans), ${ }^{40}$ mollusks (Mya arenaria) ${ }^{41}$ and arthropods (Drosophila melanogaster $).{ }^{42}$ Concerning earthworms, some efforts to identify an AHR-homolog in Eisenia fetida with RT-PCR analysis were not successful. ${ }^{43}$

The filter paper exposure assay showed that earthworms exposed to higher concentrations of PCDD/Fs (C3 and C4) exhibited surface lesions; this reflected that worms were affected by dioxins either through skin and/or by feeding. Previous studies have demonstrated that earthworm skin has direct contact with the contaminated soils and is considered as a significant route to uptake of toxicants. ${ }^{44,45}$ It was also suggested that these toxicants passing through the skin reach the cœlomic fluid and were then transported into all the body. ${ }^{46}$ In our study, the observable morphological abnormalities like coiling and mucus secretion revealed that the contact toxicity of PCDD/Fs through skin of $E$. andrei, increased with increasing concentration. Our results were consistent with the work of Chakra Reddy et al. on the contact toxicity of profenofos pesticide (PFF) through skin of $E$. foetida, in which, it was found that the toxicity of PFF increased with increasing concentration, and the same observations were noticed.

Cœlomocyte cell yield, quantified using a light microscope, showed significant low levels at all the various PCDD/Fs concentrations tested compared to controls (Figure 4). Numerous studies have demonstrated the relationship between cell yield and worm weight and proved that cell yield is a linear function of body weight. ${ }^{26}$ However, in the present experiments, the time of exposure was very short $(3 \mathrm{~h})$ and the weight lost was very negligible and this parameter (body weight) was not considered (data not shown). In a recent study on mammalian laboratory model, it was found that TCDD exposure of mice immunized with ovalbumin (OVA) decreased the splenocyte numbers and also decreased the production of cytokines by splenocytes at lower doses of TCDD. ${ }^{47}$

The viability of extruded cœlomocytes seems to be not affected by the PCDD/Fs con-

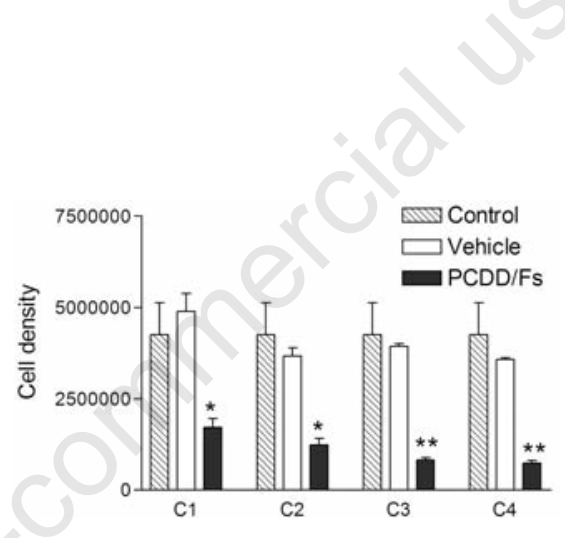

Figure 4. Effects of various concentrations of polychlorinated dibenzo- $p$-dioxins/ dibenzofurans (PCDDs/Fs) on extruded cell yield of $E$. andrei earthworms. Asterisks represent significant difference compared with vehicle controls $\left({ }^{*} \mathbf{P}<0.05\right.$; $\left.{ }^{* *} \mathbf{P}<0.01\right)$.

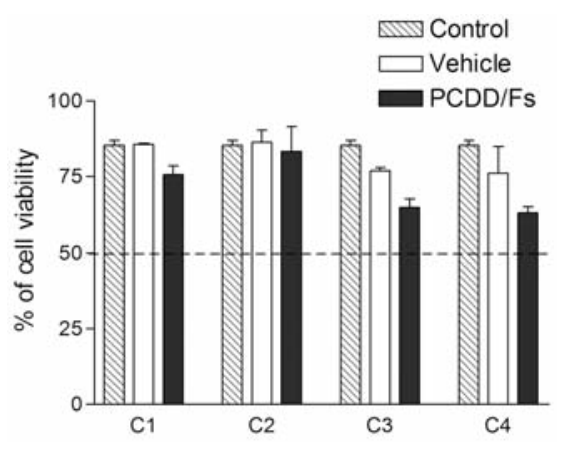

Figure 5. Effects of various concentrations of polychlorinated dibenzo-p-dioxins/ dibenzofurans (PCDDs/Fs) on the viability of the extruded cells of $E$. andrei earthworms. centrations (Figure 5). This indicated that the adverse effects noted were not the result of decreased cell viability.

The measurement of the phagocytic response of earthworm's cœlomocytes revealed that PCDD/Fs inhibited the phagocytic activity (Figure 6) and efficiency (Figure 7) at $\mathrm{C} 2, \mathrm{C} 3$ and $\mathrm{C} 4$ containing $0.276,0.553$ and $0.829 \mathrm{ng} 2378-\mathrm{TCDD} / \mathrm{cm}^{2}$, respectively. Since PCDDs/Fs and PCBs belong to persistent organic pollutants (POPs) class, our results may be consistent with two published reports on the toxicity of $\mathrm{PCBs}^{6,7}$ which showed that phagocytic competence was inhibited by polychlorinated biphenyls (PCBs). A decrease in immune function may have adverse effects on the survival of organisms. Furthermore, chemical-induced immune suppression may increase susceptibility, incidence and severity of infectious diseases. . $^{23,34,35}$

In summary, our study showed that the effects of PCDD/Fs mixtures on phagocytosis tested in vitro were somewhat difficult to quantify because of hormesis and cell mortality. However, the in vivo effects include not only the inhibition of the phagocytosis, but also

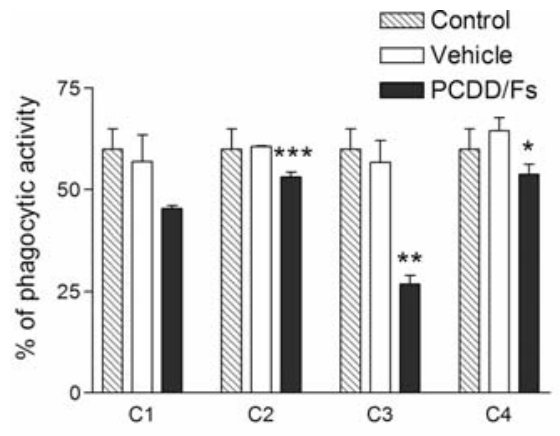

Figure 6. Effects of various concentrations of polychlorinated dibenzo- $p$-dioxins/ dibenzofurans (PCDDs/Fs) on the phagocytic activity of the extruded cells of $E$. andrei earthworms. Asterisks represent significant difference compared with vehicle controls ( $^{*}$ $\left.\mathbf{P}<0.05 ;^{* *} \mathbf{P}<0.01 ;{ }^{* * *} \mathbf{P}<0.001\right)$.

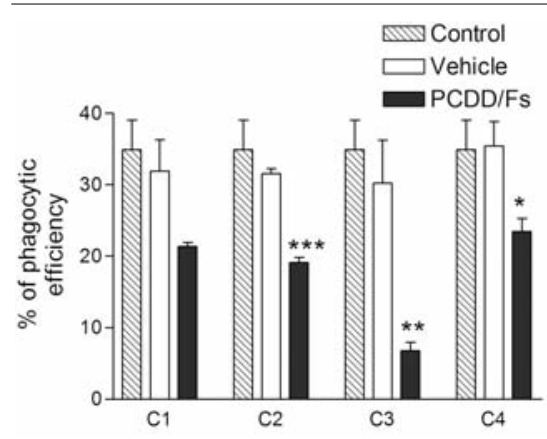

Figure 7. Effects of various concentrations of polychlorinated dibenzo- $p$ dioxins/dibenzofurans (PCDDs/Fs) on the phagocytic efficiency of the extruded cells of $E$. andrei. Asterisks represent significant difference compared with vehicle controls (* $\mathbf{P}<0.05$; ${ }^{* *} \mathbf{P}<0.01$; $\left.{ }^{* * *} \mathbf{P}<\mathbf{0 . 0 0 1}\right)$. 
exhibited significant morphological changes in the body wall which suggested that further histopathological study is necessary to develop our inderstanding of morphological alterations and histological responses caused by PCDD/Fsexposure.

\section{References}

1. OECD. Guidelines for testing of chemicals. Earthworm reproduction tests (Eisenia fetida/andrei). Paris, France: Organization for Economic Cooperation and development; Draft Document, January 2000.

2. Homa J, Olchawa E, Stürzenbaum SR, John Morgan A, Plytycz B. Early-phase immunodetection of metallothionein and heat shock proteins in extruded earthworm coelomocytes after dermal exposure to metal ions. Environ Pollut 2005;135:27580 .

3. Asensio V, Kille P, Morgan AJ, Soto M, Marigomez I. Metallothionein expression and Neutral Red uptake as biomarkers of metal exposure and effect in Eisenia fetida and Lumbricus terrestris exposed to $\mathrm{Cd}$. Eur J Soil Biol 2007;43 Suppl 1:S233-S8.

4. Lee BT, Kim KW. Arsenic accumulation and toxicity in the earthworm Eisenia fetida affected by chloride and phosphate. Environ Toxicol Chem 2008;27:2488-95.

5. Cooper EL, Roch P. Earthworm immunity: a model of immune competence: The 7th international symposium on earthworm ecology · Cardiff · Wales · 2002. Pedobiologia 2003;47:676-88.

6. Goven AJ, Shing Chong C, Fitzpatrick LC, Venables BJ. Lysozyme activity in earthworm (Lumbricus terrestris) coelomic fluid and coelomocytes: Enzyme assay for immunotoxicity of xenobiotics. Environ Toxicol Chem 1994;13:607-13.

7. Ville P, Roch P, Cooper EL, Masson P, Narbonne JF. PCBs increase molecularrelated activities (lysozyme, antibacterial, hemolysis, proteases) but inhibit macrophage-related functions (phagocytosis, wound healing) in earthworms. $\mathrm{J}$ Invertebr Pathol 1995;65:217-24.

8. Komiyama K, Okaue M, Miki Y, Ohkubo M, Moro I, Cooper EL. Non-specific cellular function of Eisenia fetida regulated by polycyclic aromatic hydrocarbons: The 7th international symposium on earthworm ecology · Cardiff · Wales · 2002. Pedobiologia 2003;47(5-6):717-23.

9. Vermeulen F, Covaci A, D'Haven H, Van den Brink NW, Blust R, De Coen W, et al. Accumulation of background levels of persistent organochlorine and organobromine pollutants through the soil-earthwormhedgehog food chain. Environ Int
2010;36:721-7.

10. Bu YQ, Luo YM, Shan ZJ, Teng Y, Li ZG. Effect of dioxin-like PCBs on physiological activities of earthworms (Eisenia fetida). Zhongguo Huanjing Kexue/China Environ Sci 2010;30:699-704.

11. Reinecke AJ, Nash RG. Toxicity of 2,3,7,8TCDD and short-term bioaccumulation by earthworms (oligochaeta). Soil Biol Biochem 1984;16:45-9.

12. Patel M, Francis J, Cooper EL, Fuller-Espie SL. Development of a flow cytometric, nonradioactive cytotoxicity assay in Eisenia fetida: An in vitro system designed to analyze immunosuppression of natural killerlike coelomocytes in response to 7,12 dimethylbenz[a] anthracene (DMBA). Eur J Soil Biol 2007;43 Suppl 1:S97-S103.

13. Alaluusua S, Calderara P, Gerthoux PM, Lukinmaa PL, Kovero 0, Needham L, et al. Developmental dental aberrations after the dioxin accident in Seveso. Environ Health Perspect 2004;112:1313.

14. Baccarelli A, Pfeiffer R, Consonni D, Pesatori AC, Bonzini M, Patterson Jr DG, et al. Handling of dioxin measurement data in the presence of non-detectable values: Overview of available methods and their application in the Seveso chloracne study. Chemosphere 2005;60:898-906.

15. Eskenazi B, Warner M, Marks AR, Samuels S, Gerthoux PM, Vercellini P, et al. Serum dioxin concentrations and age at menopause. Environ Health Perspect 2005;113: 858-62.

16. Wyde ME, Cambre T, Lebetkin M, Eldridge SR, Walker NJ. Promotion of altered hepatic foci by 2,3,7,8-tetrachlorodibenzo-pdioxin and 17B-estradiol in male SpragueDawley rats. Toxicol Sci 2002;68:295-303.

17. Lin $\mathrm{PH}$, Lin $\mathrm{CH}$, Huang $\mathrm{CC}$, Chuang $\mathrm{MC}$, Lin P. 2, 3, 7, 8-Tetrachlorodibenzo-p-dioxin (TCDD) induces oxidative stress, DNA strand breaks, and poly (ADP-ribose) polymerase-1 activation in human breast carcinoma cell lines. Toxicol Lett 2007;172: 146-58.

18. IARC. Polychlorinated dibenzo-para-dioxine and polychlorinated dibenzofurans. Lyon, France: IARC, International Agency for Research on Cancer; 1997.

19. ATSDR. Toxicological profile for chlorinated dibenzo-p-dioxins. USA: Department of Health and Human Services, Public Health Service; December 1998.

20. ATSDR. Dioxins. USA: Division of Toxicology and Environmental Medicine (DTEM), March 2006.

21. Pohl H, DeRosa C, Holler J. Public health assessment for dioxins exposure from soil. Chemosphere 1995;31:2437-54.

22. Goven AJ, Fitzpatrick LC, Venables BJ. Chemical toxicity and host defense in earthworms. An invertebrate model. Ann N
Y Acad of Sci 1994;712:280-300.

23. Fournier M, Cyr D, Blakley B, Boermans H, Brousseau P. Phagocytosis as a biomarker of immunotoxicity in wildlife species exposed to environmental xenobiotics. Am Zool 2000;40:412-20.

24. Sauvé S, Hendawi M, Brousseau P, Fournier M. Phagocytic response of terrestrial and aquatic invertebrates following in vitro exposure to trace elements. Ecotoxicol Environ Saf 2002;52:21-9.

25. Massicotte R, Robidoux PY, Sauvé S, Flipo D, Fournier M, Trottier B. Immune response of earthworms (Lumbricus terrestris, Eisenia andrei and Aporrectodea tuberculata) following in situ soil exposure to atmospheric deposition from a cement factory. J Environ Monit 2003;5: 774-9.

26. Sauvé S, Fournier M. Age-specific immunocompetence of the earthworm Eisenia andrei: Exposure to methylmercury chloride. Ecotoxicol Environ Saf 2005;60:67-72.

27. Brousseau P, Fugère N, Bernier J, Coderre D, Nadeau D, Poirier G, et al. Evaluation of earthworm exposure to contaminated soil by cytometric assay of coelomocytes phagocytosis in Lumbricus terrestris (Oligochaeta). Soil Biol Biochem 1997;29: 681-4.

28. Brousseau P, Payette Y, Tryphonas H, Blakley B, Boernaus H, Flipo D, et al. Manual of immunological methods. Boca Raton, FL: CRC Press; 1999.

29. OECD. Guidelines for testing of chemicals. Earthworm acute toxicity tests. Paris, France: Organization for Economic Cooperation and development; 1984.

30. Vernile P, Fornelli F, Bari G, Spagnuolo M, Minervini F, de Lillo E, et al. Bioavailability and toxicity of pentachlorophenol in contaminated soil evaluated on coelomocytes of Eisenia andrei (Annelida: Lumbricidae). Toxicol in Vitro 2007;21:302-7.

31. Stein E, Avtalion RR, Cooper EL. The coelomocytes of the earthworm Lumbricus terrestris: Morphology and phagocytic properties. J Morphol 1977;153:467-77.

32. Homa J, Bzowska M, Klimek M, Plytycz B. Flow cytometric quantification of proliferating coelomocytes non-invasively retrieved from the earthworm, Dendrobaena veneta. Develop Comp Immunol 2008;32:9-14.

33. Plytycz B, Kielbasa E, Grebosz A, Duchnowski M, Morgan AJ. Riboflavin mobilization from eleocyte stores in the earthworm Dendrodrilus rubidus inhabiting aerially-contaminated Ni smelter soil. Chemosphere 2010;81:199-205.

34. Descotes J, Choquet-Kastylevsky G, Van Ganse E, Vial T. Responses of the immune system to injury. Toxicol Pathol 2000;28: 479-81. 
35. Frouin H, Lebeuf M, Saint-Louis R, Hammill M, Pelletier E, Fournier M. Toxic effects of tributyltin and its metabolites on harbour seal (Phoca vitulina) immune cells in vitro. Aquat Toxicol 2008;90:24351.

36. Rozman KK, Lebofsky M, Pinson DM. Chronic toxicity and carcinogenicity of 1,2,3,4,6,7,8-heptachlorodibenzo-p- dioxin displays a distinct dose/time toxicity threshold ( $\mathrm{c} x \mathrm{xt}=\mathrm{k}$ ) and a life-prolonging subthreshold effect. Food Chem Toxicol 2005;43:729-40.

37. Zapponi GA, Marcello I. Low-dose risk, hormesis, analogical and logical thinking. Ann N Y Acad of Sci 2006;1076;839-57.

38. Omara F0, Flipo D, Brochu C, Denizeau F, Brousseau P, Potworowski EF, et al. Lack of suppressive effects of mixtures containing low levels of methylmercury (MeHg), polychlorinated dibenzo-p-dioxins (PCDDs), polychlorinated dibenzofurans (PCDFs), and Aroclor biphenyls (PCBs) on mixed lymphocyte reaction, phagocytic, and natural killer cell activities of rat leukocytes in vitro. J Toxicol Environ Health A
1998;54:561-77.

39. Marshall NB, Kerkvliet NI. Dioxin and immune regulation: Emerging role of aryl hydrocarbon receptor in the generation of regulatory T cells. Ann N Y Acad Sci 2010;1183:25-37.

40. Powell-Coffman JA, Bradfield CA, Wood WB. Caenorhabditis elegans orthologs of the aryl hydrocarbon receptor and its heterodimerization partner the aryl hydrocarbon receptor nuclear translocator. Proc Natl Acad Sci U S A 1998;95:2844-9.

41. Butler RA, Kelley ML, Powell WH, Hahn ME, Van Beneden RJ. An aryl hydrocarbon receptor (AHR) homologue from the softshell clam, Mya arenaria: evidence that invertebrate AHR homologues lack 2,3,7,8tetrachlorodibenzo-p-dioxin and betanaphthoflavone binding. Gene 2001;278: 223-34.

42. McMillan BJ, Bradfield CA. The Aryl Hydrocarbon Receptor sans Xenobiotics: Endogenous Function in Genetic Model Systems. Mol Pharmacol 2007;72:487-98.

43. Wiesner L, Hahn ME, Karchner SI, Cooper EL, Kauschke E. Does an ARYL HYDRO-
CARBON RECEPTOR (AHR)-like molecule exist in earthworms? Some implications for immunity. Pedobiologia 2003;47:64650 .

44. Saxe JK, Impellitteri CA, Peijnenburg WJGM, Allen HE. Novel model describing trace metal concentrations in the earthworm, Eisenia andrei. Environ Sci Technol 2001;35:4522-9.

45. Jager T, Fleuren RHLJ, Hogendoorn EA, de Korte G. Elucidating the Routes of Exposure for Organic Chemicals in the Earthworm, Eisenia andrei (Oligochaeta). Environ Sci Technol 2003;37:3399-404.

46. Chakra Reddy N, Venkateswara Rao J. Biological response of earthworm, Eisenia foetida (Savigny) to an organophosphorous pesticide, profenofos. Ecotoxicol Environ Saf 2008;71:574-82.

47. Ao K, Suzuki T, Murai H, Matsumoto M, Nagai H, Miyamoto Y, et al. Comparison of immunotoxicity among tetrachloro-, pentachloro-, tetrabromo- and pentabromodibenzo-p-dioxins in mice. Toxicology 2009;256:25-31. 